\title{
PENGARUH KOMBINASI TEPUNG SAGU DAN TEPUNG UDANG REBON TERHADAP KARAKTERISTIK KIMIA DAN ORGANOLEPTIK MAKARONI
}

\author{
Suparmi $^{{ }^{*}}$, Sumarto ${ }^{1}$, Nur Ira Sari ${ }^{1}$, Taufik Hidayat ${ }^{2^{*}}$ \\ ${ }^{1}$ Departemen Teknologi Hasil Perikanan, Fakultas Perikanan dan Ilmu Kelautan Universitas Riau \\ ${ }^{2}$ Pusat Teknologi Agroindustri, Badan Pengkajian dan Penerapan Teknologi, Gedung Laptiab, \\ Puspiptek Serpong
}

Diterima: 25 Maret 2021/Disetujui: 1 Juli 2021

*Korespondensi: teten_58@yahoo.co.id

\begin{abstract}
Cara sitasi: Suparmi, Sumarto, Sari NI, Hidayat T. 2021. Pengaruh kombinasi tepung sagu dan tepung udang rebon terhadap karakteristik kimia dan organoleptik makaroni. Jurnal Pengolahan Hasil Perikanan Indonesia. 24(2): 218-226.
\end{abstract}

\begin{abstract}
Abstrak
Penelitian ini bertujuan untuk menentukan karakteristik dari makaroni tepung sagu yang difortifikasi dengan tepung udang rebon. Metode yang digunakan adalah metode eksperimen menggunakan rancangan acak lengkap, dengan perlakuan tiga kombinasi antara tepung sagu dan tepung udang rebon yaitu MS0 (kontrol tanpa tepung udang rebon), $\mathrm{MS}_{1}$ (kombinasi 2:1) dan $\mathrm{MS}_{2}$ (kombinasi 1:1) diulang sebanyak 3 kali. Parameter yamg diuji yaitu mutu proksimat (kadar air, abu, protein, lemak, dan karbohidrat), daya serap air serta mutu organoleptik (rupa, tekstur, aroma, rasa). Hasil penelitian menunjukkan bahwa pada pembuatan makaroni tepung sagu dengan penambahan tepung udang rebon berpengaruh nyata terhadap nilai proksimat, daya serap air, dan nilai organoleptik. Perlakuan terbaik adalah MS (kombinasi 2:1) memiliki karakteristik rupa dengan warna kuning cerah, aroma tidak amis udang, tekstur padat tidak keras, dan rasa gurih. Nilai kadar protein $(19,67 \%)$ air $(6,98 \%)$, lemak $(4,13 \%)$, abu (2,57\%), dan karbohidrat (by difference) $65,65 \%$. Penambahan tepung udang rebon sebanyak 50 persen dapat meningkatkan protein, abu, dan lemak yang berpotensi untuk pangan fungsional.
\end{abstract}

Kata kunci : Acetes erythraeus, fortifikasi, kandungan gizi, kombinasi, pasta

\section{Characteristics of makaroni based on sago flour, combined with rebon shrimp flour (Acetes erythraeus)}

\begin{abstract}
This study was aimed to determine the characteristics of fortified sago flour macaroni with rebon shrimp flour. The method used is an experimental method using a completely randomized design, with three combinations of sago flour and rebon shrimp flour, namely MS0 (control without rebon shrimp flour), $\mathrm{MS}_{1}$. (combination 2:1) and $\mathrm{MS}_{2}$ (combination 1:1) is repeated 3 times. The parameters tested were proximate quality (water content, ash content, protein content, fat content, and carbohydrate content), water absorption capacity and organoleptic quality (appearance, texture, aroma, taste). The results showed that the making of sago flour macaroni with the addition of rebon shrimp flour had a significant effect on the proximate value, water absorption and organoleptic value. The best treatment is $\mathrm{MS}_{1}$ (2:1 combination) which has visual characteristics with bright yellow color, fishy aroma of shrimp, solid texture not hard, and savory taste. The value of protein (19.67\%) water (6.98\%), fat (4.13\%), ash (2.57\%), and carbohydrates (by difference) was $65.65 \%$. Over all, the addition of rebon shrimp flour as much as 50 percent can increase protein, ash, and fat which have the potential for functional food.
\end{abstract}

Keywords : Acetes erythraeus, combination, fortification, nutrient content, pasta 


\section{PENDAHULUAN}

Makaroni merupakan bahan makanan yang berbentuk buluh pita terbuat dari campuran tepung terigu dengan telur. Produk makaroni banyak dimanfaatkan dalam menu makanan di restoran dan juga hotel-hotel berbintang. Makaroni sangat praktis dalam penyajian, bentuk dan jenis yang bervariasi, mudah dikemas. Produk ini digemari oleh banyak kalangan, mulai dari anak-anak hingga orang dewasa. Saat ini yang lebih dikenal adalah makaroni berbahan baku tepung terigu, sedangkan makaroni dengan bahan baku tepung sagu belum ada. Tepung sagu hanya dikenal oleh sekelompok orang pada daerah tertentu. Menurut Mazlina et al. (2007) bahwa tepung sagu berpotensi menjadi sumber pangan alternatif dengan kandungan karbohidrat tinggi tetapi kandungan proteinnya rendah. Oleh karena itu, makaroni yang berbahan dasar tepung sagu perlu dilakukan fortifikasi zat gizi misalnya protein dan mikronutrien lainnya sehingga produk berbasis tepung sagu memiliki potensi besar sekaligus memperluas pemasaran dan menghasilkan produk yang berkualitas .

Bahan yang dapat dipakai sebagai penambah nilai gizi adalah tepung udang rebon. Tepung udang rebon memiliki gizi yang tinggi terutama kandungan proteinnya yaitu 59,4\%, keunggulan lainnya adalah tingginya kandungan asam amino glutamat yang mengindikasikan adanya potensi yang dapat menambah rasa gurih, serta kaya akan fosfor dan kalsium. (Suparmi et al. 2020).

Pemanfaatan tepung udang rebon sebagai bahan fortifikasi pada makaroni berbahan dasar tepung sagu merupakan salah satu upaya diversifikasi sehingga dapat meningkatkan nilai tambah dari produk tersebut. Oleh karena itu, diharapkan pembuatan makaroni yang difortifikasi dengan tepung udang rebon dapat menjadi alternatif masyarakat untuk mengonsumsi makanan pasta yang bergizi dan menyehatkan.

Penelitian ini bertujuan untuk menentukan pengaruh dari pemberian tepung udang rebon yang dikombinasikan dengan tepung sagu terhadap karakteristik makaroni.

\section{BAHAN DAN METODE Bahan dan Alat}

Bahan yang digunakan pada pembuataan makaroni adalah tepung sagu dan tepung udang rebon, sedangkan untuk bahan analisis yaitu $\mathrm{H}_{2} \mathrm{SO}_{4}$ (Merck), $\left[\mathrm{Cu}\left(\mathrm{NH}_{3}\right)_{4}\right]_{2}$ (Merck), akuades, indikator pp, $\mathrm{NaOH} 50 \%$ (Merck), $\mathrm{H}_{3} \mathrm{BO}_{3}(2 \%)$ (Merck), $\mathrm{HCl}(0,1 \mathrm{~N})$ (Merck), indikator campuran (metilin merah-biru), dietil eter dan bahan kimia lainnya.

Alat yang digunakan adalah ekstruder, oven pengering, uji warna Lovibond Tintometer model F, dan uji tekstur Pil Hardness Tester 0219.

\section{Metode Penelitian}

Penelitian dilakukan dengan teknologi formulasi dengan melakukan kombinasi tepung antrara sagu dan tepung udang rebon. Perlakuan $\mathrm{MS}_{0}$ (tanpa penambahan tepung udang rebon) sebagai kontrol, $\mathrm{MS}_{1}$ (kombinasi sagu dan rebon 2:1) dan $\mathrm{MS}_{2}$ (kombinasi sagu dan rebon 1:1).

\section{Pembuatan tepung udang rebon}

Udang rebon dibersihkan dan dicuci, ditiriskan selama 15 menit, selanjutnya dikeringkan selama 1 jam di dalam oven dengan suhu $70{ }^{\circ} \mathrm{C}$. Tahap selanjutnya dilakukan penggilingan dengan blender dan diayak (60 mesh), diperoleh tepung udang rebon.

\section{Pembuatan makaroni.}

Pembuatan makaroni menggunakan tepung sagu, tepung tapioka ditambah tepung udang rebon. Bahan tambahan yaitu telur, garam, air dicampur sesuai formulasi. Diadon hingga merata sempurna didiamkan selama 20 menit, kemudian dibentuk seperti elbow menggunakan mesin ekstruder. Tahap selanjutnya dikukus selama 10 menit dan dikeringkan dalam oven pada suhu $70{ }^{\circ} \mathrm{C}$ selama 2,5 jam. Parameter yang diuji adalah proksimat, organoleptik dan daya serap air. Perlakuan formulasi dapat dilihat pada Table 1. 
Table 1 Effect of soaking time on consumer acceptance of Sargassum crassifolium seaweed tea

\begin{tabular}{lrrr}
\multirow{2}{*}{ Component } & \multicolumn{3}{c}{ Formulation } \\
\cline { 2 - 4 } & $\mathrm{MS}_{0}$ & $\mathrm{MS}_{1}$ & $\mathrm{MS}_{2}$ \\
\hline Sagu flour $(\mathrm{g})$ & 200 & 200 & 200 \\
Tapioca flour (g) & 50 & 50 & 50 \\
Shrimp rebon flour (g)* & - & 100 & 200 \\
Egg (grain) & 50 & 50 & 50 \\
Salt (g) & 5 & 5 & 5 \\
Water g) & 70 & 70 & 70 \\
\hline
\end{tabular}

\section{Prosedur analisis}

\section{Analisis proksimat}

Analisis proksimat dilakukan untuk melihat kandungan gizi dalam tepung udang rebon Pengujian proksimat meliputi kadar air dengan oven, protein dengan kjedahl, abu dengan trigivonometri, kadar lemak dengan sokhlet, dan karbohidrat by difference.

\section{Kadar air (AOAC 2005)}

Tahap pertama yang dilakukan untuk menganalisis kadar air adalah cawan tembikar dikeringkan dalam oven pada suhu $105{ }^{\circ} \mathrm{C}$ selama 1 jam. Cawan tersebut diletakkan ke dalam desikator (kurang lebih 15 menit) dan dibiarkan sampai dingin kemudian ditimbang. Contoh sebanyak $5 \mathrm{~g}$ dimasukkan ke dalam cawan tersebut, dikeringkan dengan oven pada suhu $105^{\circ} \mathrm{C}$ selama 5-8 jam atau hingga beratnya konstan. Setelah selesai proses, cawan tersebut didinginkan dalam desikator \pm 30 menit dan dibiarkan sampai dingin dan selanjutnya ditimbang kembali. Perhitungan kadar air dilakukan dengan rumus:

$\%$ Kadar air $=\frac{\text { B-C }}{\text { B-A }} \times 100 \%$

Keterangan:

A: berat cawan kosong ( $\mathrm{g}$ )

B: berat cawan + sampel awal $(\mathrm{g})$

C: berat cawan + sampel kering $(\mathrm{g})$ )

\section{Kadar lemak (AOAC 2005)}

Sampel seberat $5 \mathrm{~g}\left(\mathrm{~W}_{1}\right)$ dimasukkan ke dalam kertas saring dan selanjutnya dimasukkan ke dalam selongsong lemak. Sampel yang telah dibungkus dimasukkan ke dalam labu lemak yang sudah ditimbang berat tetapnya $\left(\mathrm{W}_{2}\right)$ dan disambungkan dengan tabung soxhlet. Selongsong lemak dimasukkan ke dalam ruang ekstraktor tabung soxhlet dan disiram dengan pelarut lemak. Tabung ekstraksi dipasang pada alat destilasi soxhlet, lalu dipanaskan pada suhu $40{ }^{\circ} \mathrm{C}$ menggunakan pemanas listrik selama 16 jam. Pelarut lemak yang ada dalam labu lemak didestilasi hingga semua pelarut lemak menguap. Pada saat destilasi pelarut akan ditampung di ruang ekstraktor, pelarut dikeluarkan sehingga tidak kembali ke dalam labu lemak, selanjutnya labu lemak dikeringkan dalam oven pada suhu $105{ }^{\circ} \mathrm{C}$, setelah itu labu didinginkan dalam desikator sampai beratnya konstan $\left(\mathrm{W}_{3}\right)$. Perhitungan kadar lemak dilakukan dengan rumus:

$\%$ Kadar lemak $=\frac{\mathrm{W} 3-\mathrm{W} 2}{\mathrm{~W} 3} \times 100 \%$

Keterangan:

$\mathrm{W} 1$ : berat sampel $(\mathrm{g})$

W2: berat labu lemak kosong (g)

W3: berat labu lemak dengan lemak (g)

\section{Kadar protein (AOAC 2005)}

Tahap-tahap yang dilakukan dalam analisis protein terdiri dari tiga tahap yaitu destruksi, destilasi, dan titrasi. Sampel ditimbang sebanyak $0,25 \mathrm{~g}$ kemudian dimasukkan ke dalam labu Kjeldahl $100 \mathrm{~mL}$, lalu ditambahkan $0,25 \mathrm{~g}$ selenium dan $3 \mathrm{~mL}$ $\mathrm{H}_{2} \mathrm{SO}_{4}$ pekat. Sampel didestruksi pada suhu $410^{\circ} \mathrm{C}$ sampai larutan jernih lalu didinginkan, kemudian ditambahkan $50 \mathrm{~mL}$ akuades dan $20 \mathrm{~mL} \mathrm{NaOH}$ 40\%, kemudian dilakukan proses destilasi. Hasil destilasi ditampung dalam labu Erlenmeyer $125 \mathrm{~mL}$ yang berisi campuran $10 \mathrm{~mL}$ asam borat $\left(\mathrm{H}_{3} \mathrm{BO}_{3}\right) 2 \%$ dan 2 tetes indikator bromokresol hijau-metil merah yang berwarna merah muda. Setelah 
volume destilat mencapai $200 \mathrm{~mL}$ maka proses destilasi dihentikan. Lalu destilat dititrasi dengan $\mathrm{HCl} 0,1 \mathrm{~N}$ sampai terjadi perubahan warna merah muda. Volume titran dibaca dan dicatat. Larutan blanko dianalisis seperti contoh. Kadar protein dihitung dengan rumus sebagai berikut:

$\% \mathrm{~N}=\frac{(\mathrm{mL} \mathrm{HCl}-\mathrm{mL} \text { blanko }) \times \mathrm{N} \mathrm{HCl} \times 14.007 \times 100 \%}{\mathrm{Mg} \text { contoh } \mathrm{x} \text { faktor koreksi alat }{ }^{*}}$

Keterangan:

$\%$ kadar protein $=\% \mathrm{~N} x$ faktor konversi ${ }^{*}$

*) Faktor koreksi alat $=2.5$

*) Faktor konversi $\quad=6.25$

\section{Kadar abu (AOAC 2005)}

Cawan pengabuan dikeringkan di dalam oven selama 1 jam pada suhu $105^{\circ} \mathrm{C}$, kemudian didinginkan di dalam desikator dan ditimbang hingga didapatkan berat yang konstan. Sampel sebanyak $5 \mathrm{~g}$ dimasukkan ke dalam cawan pengabuan dan dipijarkan di atas nyala api bunsen hingga tidak berasap lagi. Setelah itu dimasukkan ke dalam tanur pengabuan dengan suhu $600{ }^{\circ} \mathrm{C}$ sampai pengabuan sempurna, kemudian ditimbang hingga didapatkan berat yang konstan. Kadar abu ditentukan dengan rumus:

$\%$ kadar abu $=\frac{\text { C-A }}{\text { B-A }} \quad \mathrm{x} 100 \%$

Keterangan:

A: berat cawan tembikar kosong $(\mathrm{g})$

B: berat cawan dengan sampel (g)

$\mathrm{C}$ : berat cawan dengan sampel setelah dikeringkan(g)

\section{Analisis karbohidrat (AOAC 2005)}

Pengukuran kadar karbohidrat dilakukan secara by difference, yaitu hasil pengurangan dari $100 \%$ dengan kadar air, $\mathrm{r}$ abu, protein, dan kadar lemak sehingga kadar karbohidrat tergantung pada faktor pengurangan. Hal ini karena karbohidrat sangat berpengaruh terhadap zat gizi lainnya.

\section{Uji organoleptik (Adawiyah et al. 2007)}

Metode yang digunakan untuk uji organoleptik ini berdasarkan uji hedonik. Metode ini menggunakan angka yang berkisar antara 1 sampai 9, mulai dari tidak suka hingga sangat suka. Pengukuran organoleptik merupakan cara penilaian mutu makaroni yang bersifat subjektif dengan menggunakan indra manusia. Jumlah panelis yang menilai adalah sebanyak 30 orang dengan kategori panelis semi terlatih.

\section{Analisis daya serap air (Beuchat 1977)}

Sampel sebanyak $0,5 \mathrm{~g}$ ditambah $5 \mathrm{~mL}$ akuades dan diaduk selama 30 detik. Lalu didiamkan selama 30 menit dalam ruangan. Kemudian sebanyak $0.15 \mathrm{ml}$ sampel tersebut dimasukkan ke dalam tabung eppendorf untuk disentrifugasi selama 30 menit pada suhu kamar dengan kecepatan $5000 \mathrm{rpm}$. Setelah terbentuk suspensi, cairan yang tidak larut dalam air atau minyak dipipet dan ditimbang (A). Rumus yang digunakan yaitu:

Daya serap air $(\%)=(0.15 \mathrm{~mL}-\mathrm{A}) / 0.15 \mathrm{~mL}$ x 100

\section{Analisis Data}

Rancangan percobaan yang digunakan dalam pembuatan makaroni adalah rancangan acak lengkap faktorial dengan 1 perlakuan yaitu, yaitu rasio penambahan tepung udang rebon rancangan acak lengkap (nested) faktorial menurut Steel dan Torrie (1993) adalah sebagai berikut:

$\mathrm{Y}_{\mathrm{ijk}}=\mu+\mathrm{A}_{\mathrm{i}}+\mathrm{B}_{\mathrm{j}}+(\mathrm{AB})_{\mathrm{ij}}+€_{\mathrm{ijk}}$

Keterangan:

$\mathrm{Y}_{\mathrm{ijk}}$ : nilai pengamatan dari faktor - A taraf ke-I,

faktor B taraf ke-J dan ulangan ke-k

$\mu$ : nilai tengah umum

$A_{i}$ : pengaruh faktor A ke- $I(I=1,2)$

$\mathrm{B}_{\mathrm{i}}$ : pengaruh faktor $\mathrm{B}$ ke- $\mathrm{J}(\mathrm{I}=1,2,3)$

$\mathrm{AB}_{\mathrm{ij}}$ : pengaruh interaksi antara faktor $\mathrm{A}$ ke-i dan

faktor B ke-j

$€_{\mathrm{ijk}}$ : galat percobaan dari faktorA taraf ke-I, faktor B taraf ke-J dan ulangan ke-K

\section{HASIL DAN PEMBAHASAN}

Proksimat makaroni yang meliputi kadar protein, air, lemak, abu dan karbohidrat, jumlahnya dipengaruhi oleh perlakuan yang diberikan Nilai proksimat yang dianalisis dari makaroni dapat dilihat pada Table 2.

\section{Kadar Protein}

Hasil penelitian didapatkan bahwa semakin tinggi fortifikasi tepung udang rebon maka nilai protein dari makaroni akan semakin tinggi yaitu pada perlakuan fortifikasi tepung 
Table 2 Proximate average value of fortified sago flour for boiled shrimp flour

\begin{tabular}{cccccr}
\hline & \multicolumn{5}{c}{ Composition (\%) } \\
\cline { 2 - 6 } Treatment & Protein & Moisture & Lipid & Ash & $\begin{array}{r}\text { Carbohydrate } \\
\text { (by difference) }\end{array}$ \\
\hline MS $_{0}$ & $17.28 \pm 0.01^{\mathrm{a}}$ & $4.52 \pm 0.02^{\mathrm{a}}$ & $3.76 \pm 0.02^{\mathrm{a}}$ & $1.45 \pm 0.02^{\mathrm{a}}$ & $76.99 \pm 0.03^{\mathrm{a}}$ \\
$\mathrm{MS}_{1}$ & $19.67 \pm 0.03^{\mathrm{b}}$ & $6.98 \pm 0.01^{\mathrm{b}}$ & $4.13 \pm 0.01^{\mathrm{b}}$ & $2.57 \pm 0.02^{\mathrm{b}}$ & $65.65 \pm 0.05^{\mathrm{b}}$ \\
$\mathrm{MS}_{2}$ & $21.59 \pm 0.01^{\mathrm{c}}$ & $7.47 \pm 0.02^{\mathrm{c}}$ & $5.25 \pm 0.02^{\mathrm{c}}$ & $2.70 \pm 0.01^{\mathrm{b}}$ & $62.99 \pm 0.02^{\mathrm{b}}$ \\
\hline
\end{tabular}

Note : same letters in the same row show significant differences $(p<0.05)$

udang rebon $\mathrm{MS}_{2}$ yaitu sebesar $21,59 \%$ dan ini berbeda nyata dengan perlakuan lainnya $(p<0,05)$. Hal ini terbukti pada bahan baku dalam pembuatan makaroni ini terdiri dari udang rebon yang kaya akan protein. Menurut Abdullah et al. (2013), protein merupakan salah satu komponen penyusun bahan pangan yang mempunyai peranan sangat besar dalam menentukan mutu produk pangan. Berdasarkan SNI 01-3777-1995 kadar protein makaroni minimum yaitu sebesar $10 \%$ hal ini menandakan bahwa kadar protein makaroni udang rebon memenuhi standar SNI.

\section{Kadar Air}

Berdasarkan hasil penelitian didapatkan kadar air makaroni tepung sagu dengan fortifikasi tepung udang rebon yaitu $\mathrm{MS}_{0}$ (4,52\%), $\mathrm{MS}_{1}$ (6,98\%), $\mathrm{MS}_{2}$ (7,47\%). Kadar air makaroni tepung sagu dengan fortifikasi tepung udang rebon mengalami kenaikan kadar air semakin tinggi jumlah fortifikasi tepung udang rebon semakin meningkat kadar air makaroni. Hal ini disebabkan berkurangnya jumlah tepung sagu sehingga kadar amilosa semakin sedikit, karena amilosa merupakan polimer tidak bercabang karenanya semakin banyak komponen amilosanya maka indeks penyerapan airnya semakin tinggi karena banyak mengandung gugus hidroksil yang bersama-sama dengan amilopektin menjadi komponen penyusun pati dan larut dalam air. Disamping itu, diduga kemampuan tepung udang rebon yang bersifat hidrofilik yang dapat mengikat air. Hidayat et al. (2013) juga menyatakan bahwa molekul amilosa bersifat hidrofilik.

\section{Kadar Abu}

Berdasarkan hasil penelitian didapatkan kadar abu makaroni tepung sagu dengan fortifikasi tepung udang rebon perlakuan yaitu $\mathrm{MS}_{0}(1,45 \%), \mathrm{MS}_{1}(2,57 \%), \mathrm{MS}_{2}(2,70 \%)$, berdasarkan hasil tersebut didapatkan kadar abu makaroni tepung sagu dengan fortifikasi tepung udang rebon belum memenuhi standar SNI 01-3777-1995 kadar abu makaroni maksimum yaitu $1 \%$. Tingginya kadar abu disebabkan dengan adanya penambahan sagu dan udang rebon yang diduga meningkatkan komponen zat mineral yang ada pada makaroni. Hasil ini juga sejalan dengan penelitian Hayati (2016) yang menghasilkan kadar abu lebih tinggi, karena penggunaan konsentrasi tepung sagu dengan kombinasi tepung tempe.

\section{Kadar Lemak}

Berdasarkan hasil penelitian didapatkan kadar lemak makaroni tepung sagu dengan fortifikasi tepung udang rebon setiap perlakuan yaitu $\mathrm{MS}_{0}(3,76 \%), \mathrm{MS}_{1}(4,13 \%)$, $\mathrm{MS}_{2}$ (5,25\%), berdasarkan hasil tersebut didapatkan kadar lemak makaroni tepung sagu dengan fortifikasi tepung udang rebon belum memenuhi standar SNI 01-3777-1995 kadar lemak makaroni maksimal yaitu 1,5\%. Hal ini juga sejalan dengan penelitian Hayati (2016) yang menyatakan bahwa kadar lemak makaroni dengan mensubsitusi terigu dengan sagu menghasilkan nilai lemak yang di atas standar SNI.

\section{Kadar Karbohidrat}

Berdasarkan hasil analisis yang dilakukan diperoleh kadar karbohidrat dengan metode by difference pada produk makaroni tepung 
sagu dengan fortifikasi tepung udang rebon $\mathrm{MS}_{0}$ (76,99\%), MS 1 (65,65\%), MS 2 (65,99\%), Perlakuan $\mathrm{MS}_{0}$ mempunyai nilai karbohidrat tertinggi dibandingkan perlakuan lainnya. Namun, ketiga perlakuan tersebut memiliki nilai yang masih dalam standar nilai SNI minimum $60 \%$.

\section{Daya Serap Air}

Hasil pengujian daya serap air makaroni tepung sagu dengan fortifikasi tepung udang rebon, menunjukkan bahwa makaroni dengan perlakuan $\mathrm{MS}_{0}$ memberikan daya serap air yang lebih tinggi dibanding perlakuan $\mathrm{MS}_{1}$ dan $\mathrm{MS}_{2}$, hal ini memberikan kecenderungan bahwa perbandingan antara tepung sagu dan tepung udang rebon yang jumlahnya tinggi, dapat dilihat pada Table 3.

Table 3 Percentage of water absorption power of sago flour fortification of boiled shrimp flourseaweed tea

\begin{tabular}{cr}
\hline Treatment & Water absorption (\%) \\
\hline $\mathrm{MS}_{0}$ & $254 \pm 0.01^{\mathrm{a}}$ \\
$\mathrm{MS}_{1}$ & $219 \pm 0.03^{\mathrm{b}}$ \\
$\mathrm{MS}_{2}$ & $207 \pm 0.01^{\mathrm{c}}$ \\
\hline
\end{tabular}

Note: same letters in the same row show significant differences $(p<0.05)$

Hasil pengujian daya serap air menunjukkan bahwa makaroni dengan perlakuan $\mathrm{MS}_{0}$ lebih tinggi dibanding perlakuan $\mathrm{MS}_{1}$ dan $\mathrm{MS}_{2}$. Hal ini memberi kecenderungan bahwa fortifikasi tepung udang rebon yang jumlahnya sama dengan tepung sagu memberikan daya serap air yang rendah. hal ini disebabkan tepung udang rebon mempunyai daya gelatinasi yang lebih rendah, Pada Table 3 terlihat bahwa semakin tinggi jumlah tepung udang rebon yang ditambahkan maka nilai daya serap air semakin rendah. Zhang et al. (2011) juga menyatakan bahwa campuran dua jenis tepung dengan porsi yang berbeda, memberikan suhu gelatinasi yang lebih tinggi, dan menurut Hidayat et al. (2013) penambahan tepung lindur yang semakin banyak menyebabkan berkurangnya daya serap air.

\section{Nilai Organoleptik}

Penilaian menggunakan score sheet yang telah disediakan. Panelis diminta untuk memberikan tanggapan terhadap makaroni fortifikasi tepung udang rebon dengan memberikan tanggapan berupa nilai. Hasil penilaian panelis dapat dilihat pada Table 4 .

\section{Kenampakan}

Berdasarkan hasil penelitian didapatkan, tingkat penerimaan konsumen pada makaroni sagu dengan fortifikasi udang rebon dengan perlakuan $\mathrm{MS}_{1}$ memiliki rupa nilai rata-rata $8,62 \pm 0,03$ dengan warna cerah kekuningan, sedangkan pada perlakuan $\mathrm{MS}_{0}$ memiliki nilai $6,18 \pm 0,01$ dengan warna kuning pudar, dan pada perlakuan $\mathrm{MS}_{2}$ memiliki nilai 6,54 $\pm 0,01$ dengan warna kuning kusam sedikit gelap. Hasil dari analisis variansi didapat bahwa perlakuan makaroni fortifikasi tepung udang rebon berpengaruh nyata terhadap nilai rupa dengan tingkat kepercayaan $(p<0,05)$. Rupa dari makaroni dipengaruhi oleh fortifikasi tepung udang rebon.

Adanya perbedaan warna makaroni diduga disebabkan oleh fortifikasi tepung udang rebon, semakin tinggi jumlah tepung udang rebon yang ditambahkan maka warna mejadi semakin kusam, sehingga rupa makaroni kurang disukai oleh panelis. Hal

Table 4 Organoleptic average value of fortified sago flour for boiled shrimp flour

\begin{tabular}{ccccr}
\hline \multirow{2}{*}{ Treatment } & \multicolumn{4}{c}{ Parameter } \\
\cline { 2 - 5 } & Appearance & Taste & Odor & \multicolumn{1}{c}{ Texture } \\
\hline $\mathrm{MS}_{0}$ & $6.18 \pm 0.01^{\mathrm{a}}$ & $5.59 \pm 0.02^{\mathrm{a}}$ & $6.46 \pm 0.02^{\mathrm{a}}$ & $6.65 \pm 0.0^{\mathrm{a}}$ \\
$\mathrm{MS}_{1}$ & $8.62 \pm 0.03^{\mathrm{b}}$ & $7.98 \pm 0.01^{\mathrm{b}}$ & $7.87 \pm 0.01^{\mathrm{b}}$ & $8.59 \pm 0.02^{\mathrm{b}}$ \\
$\mathrm{MS}_{2}$ & $6.54 \pm 0.01^{\mathrm{c}}$ & $7.45 \pm 0.02^{\mathrm{c}}$ & $7.24 \pm 0.02^{\mathrm{c}}$ & $7.70 \pm 0.01^{\mathrm{c}}$ \\
\hline
\end{tabular}

Note: same letters in the same row show significant differences $(p<0.05)$ 
ini karena dalam tepung udang rebon diduga mengandung pigemen yang disebabkan oleh adanya astaxhantin (Nurjanah et al. 2016). Rupa adalah salah satu faktor yang memengaruhi daya terima konsumen. Gobel et al. (2016) menyatakan bahwa rupa merupakan salah satu parameter dalam organoleptik yang paling penting dan merupakan faktor yang pertama kali dilihat oleh konsumen dan umumnya konsumen cenderung lebih memilih produk yang memiliki rupa yang utuh, tidak cacat, warna cemerlang dan menarik. Suparmi et al. (2020) dan Hidayat et al. (2013) juga menyatakan bahwa rupa merupakan hal utama yang menjadi perhatian konsumen karena apabila semakin menarik rupa suatu produk, maka konsumen akan semakin tertarik untuk mencoba produk tersebut dan sebaliknya apabila rupa suatu produk tidak menarik, maka akan menurunkan keinginan atau daya tarik konsumen terhadap suatu produk.

\section{Aroma}

Berdasarkan hasil penelitian perlakuan MS ${ }_{1}$ memiliki aroma yang disukai oleh panelis, sedangkan pada perlakuan $\mathrm{MS}_{0}$ memiliki aroma khas sagu, sedangkan pada perlakuan $\mathrm{MS}_{2}$ memiliki aroma udang rebon yang dominan. Nilai aroma makaroni pada perlakuan $\mathrm{MS}_{1}$ ini lebih disukai karena memiliki aroma udang rebon yang tidak terlalu kuat dibandingkan dengan perlakuan lainnya. Hasil dari analisis variansi didapat bahwa perlakuan dengan fortifikasi tepung udang rebon berpengaruh nyata terhadap nilai aroma makaroni $(p<0,05)$

Semakin banyak jumlah tepung udang rebon yang ditambahkan, maka makaroni yang dihasilkan akan beraroma udang yang sangat kuat, dan aroma udang yang kuat ini mengurangi tingkat penilaian panelis. Perlakuan MS memiliki aroma terbaik yang khas udang rebon dengan memiliki rata rata $7,87 \pm 0,01$. Abdullah et al. (2017) menyatakan bahwa asam-asam amino dan lemak dari suatu produk akan menimbulkan aroma yang khas.

Aroma dari suatu produk terdeteksi ketika zat yang menguap (volatil) dari produk tersebut terhirup dan diterima oleh sistem penciuman (Dewantara et al. 2019). Selanjutnya Amrullah (2015), menyatakan bahwa melalui aroma, panelis dapat mengetahui bahan-bahan yang terkandung dalam suatu produk. Aroma biasanya muncul dari bahan yang diolah karena senyawa volatil yang terdapat dalam bahan pangan keluar melalui proses pengolahan atau perlakuan tertentu.

\section{Tekstur}

Hasil penelitian pada perlakuan $\mathrm{MS}_{1}$ memiliki tekstur agak elastis dan tidak keras, sedangkan pada perlakuan $\mathrm{MS}_{0}$ memiliki tekstur keras, pada perlakuan $\mathrm{MS}_{2}$ memiliki tekstur kompak dan sedikit keras dan pada perlakuan formula $\mathrm{MS}_{3}$ memiliki tekstur kompak dan keras. Tekstur merupakan parameter organoleptik yang juga penting karena sifat sensori yang pertama dilihat oleh konsumen selain warna.

Menurut Erwinsyah (2015), bahwa banyak hal yang memengaruhi tekstur pada bahan pangan, di antaranya adalah rasio kandungan protein, lemak, suhu pengolahan, dan kandungan air. Hal ini terbukti bahwa pada setiap perlakuan yang memiliki formulasi air yang sama. Kemudian pendapat ini juga didukung oleh Nurjanah et al. (2015), bahwa peningkatan tekstur dari produk pangan ditentukan oleh besarnya kandungan protein dalam produk pangan tersebut, dikarenakan ikatan peptida yang panjang sehingga tidak mudah untuk memutuskan ikatan tersebut dan menghasilkan tekstur yang keras. Nilai rata-rata tekstur makaroni tepung sagu dengan penambahan tepung udang rebon berturut-turut adalah 6,$65 ; 8,89$; dan 7,70 dengan perlakuan $\mathrm{MS}_{1}$ adalah perlakuan terbaik dibandingkan perlakuan lainnya.

Semakin tinggi konsentrasi tepung udang rebon yang ditambahkan, maka tingkat kesukaan panelis terhadap tekstur semakin kecil. Hal ini disebabkan karena penambahan tepung udang rebon yang berlebih menyebabkan tekstur menjadi keras (Gobel et al. 2016).

\section{Rasa}

Hasil penelitian pada perlakuan $\mathrm{MS}_{1}$ memiliki rasa gurih udang rebon dengan nilai 
7,98, karena itu makaroni pada perlakuan $\mathrm{MS}_{1}$ ini lebih disukai oleh panelis, sedangkan perlakuan $\mathrm{MS}_{2}$ kurang disukai oleh panelis karena memiliki rasa khas udang rebon lebih dominan dan sedikit amis, perlakuan $\mathrm{MS}_{0}$ tidak disukai oleh panelis karena rasanya tidak gurih dan sedikit tawar. Rasa dari suatu produk makanan adalah faktor yang sangat penting, karena rasa dapat menentukan tingkat penerimaan konsumen terhadap suatu produk. Menurut Suryono (2013), rasa suatu bahan pangan berasal dari bahanbahan itu sendiri dan apabila telah mendapat proses pengolahan maka rasanya dipengaruhi oleh bahan-bahan yang ditambahkan dalam proses pengolahan. Rasa memegang peranan penting dalam menentukan keputusan akhir konsumen untuk menerima atau menolak suatu makanan. Meskipun hasil penelitian terhadap parameter kandungan protein $\mathrm{MS}_{1}$ lebih baik dari $\mathrm{MS}_{3}$, tetapi jika rasa produk memberikan penilaian tidak enak maka produk tersebut akan ditolak oleh konsumen (Fellows 2000). Selanjutnya Anggo et al. (2014) kandungan asam amino yang terdapat pada udang rebon yang dominan adalah asam glutamat.

\section{KESIMPULAN}

Berdasarkan hasil penelitian maka dapat disimpulkan bahwa pada pembuatan makaroni tepung sagu dengan fortifikasi tepung udang rebon berpengaruh nyata terhadap nilai proksimat, daya serap air dan nilai organoleptik. Perlakuan terbaik menurut panelis adalah formula $\mathrm{MS}_{1}$ memiliki karakteristik rupa dengan warna kuning cerah, aroma tidak amis udang, tekstur padat tidak keras, dan rasa gurih. Secara keseluruhan parameter makaroni tepung sagu dengan perlakuan penambahan 50\% tepung udang rebon memenuhi standar SNI, kecuali untuk lemak dan abu.

\section{DAFTAR PUSTAKA}

Abdullah A, Nurjanah, Hidayat T, Chairunisah R. 2017. Karakteristik kimiawi Meretrix meretrix, Pholas dactylus, dan Babylonia spirata. Jurnal Teknologi dan Industri Pangan. 28(1): 78-84
Abdullah A, Nurjanah, Hidayat T, Yusefi Y. 2013. Profil asam amino dan asam lemak kerang bulu (Anadara antiquata). Jurnal Pengolahan Hasil Perikanan Indonesia. 16(2): 159-167.

Adawyah DR, Waysima, Indrasti D. 2007. Penuntun Praktikum Evaluasi Sensori. Fateta IPB. Bogor.

Amrullah, W.S. 2015. Mutu organoleptik dan kimiawi stik rumput laut Kappaphycus alvarezii dengan penambahan udang rebon (Mysis sp.). [Skripsi]. Gorontalo: Jurusan Teknologi Hasil Perikanan Fakultas Perikanan Dan Ilmu Kelautan. Universitas Negeri Gorontalo.

Anggo DA, Swastawati F, Ma'rufFW Rianingsih L. 2014. Mutu organoleptik dan kimiawi terasi udang rebon dengan kadar garam berbeda dan lama fermentasi. Jurnal Pengolahan Hasil Perikanan. 17(1): 53-59.

[AOAC]. Association of Official Analytical Chemistry International. 2005. Official Method of Analysis. Association of Official Analytical Chemistry International, Gaithersburg.

[BSN]. Badan Standardisasi Nasional.1995. SNI-01-3777-1995.Makaroni.Jakarta (ID): Badan Standardisasi Nasional Indonesia.

Beuchat LR. 1977. Functional and electrophoretic characteristics of succinylated peanut flour protein. Journal Agriculture. Food Chemistry. 25 (6) : 258261.

Dewantara EC, Wijayanti I, Apri DA. 2019. Karakteristik fisiko kimia dan sensori pasta makaroni dengan penambahan tepung ikan gabus (Channa striata). semarang. Jurnal Ilmu Dan Teknologi Perikanan.1(2): 22-29.

Erwinsyah. 2015. Pengaruh Fortifikasi Alga Hijau Biru (Spirulina) Pada Makaroni Ikan Patin (Pangasius hypophtalmus) Terhadap Penerimaan Konsumen. [Skripsi]. Riau: Universitas Riau.

Gobel RV, Asri SN, Nikmawatisusanti Y. 2016. Formulasi Cookies Udang Rebon. Nike Jurnal Ilmiah Perikanan dan Kelautan. 107-112.

Fellows, P. 2000. Food Processing Technology Principles and Practice. (EN): Ellis 
Howood Limited.

Hayati H. 2016. Karakterisasi fisiokimia produk makaroni hasil substitusi tepung sagu terhadap tepung terigu dengan penambahan protein dari tepung tempe. [Skripsi]. Padang: Univesitas Andalas.

Hidayat T, Nurjanah, Suptijah P. 2013. Karakterisasi tepung buah lindur (Bruguiera gymnorrhiza) sebagai beras analog dnegan penambahan sagu dan kitosan. Jurnal Pengolahan Hasil Perikanan Indonesia. 16(3): 268-277.

Kusnandar F. 2011. Kimia Pangan Komponen Makro. Bogor (ID): Dian Rakyat.

Mazlina MKS, Siti NM, Siti AH, Fakhrul RA. 2007. Improvement on sago flour processing. International Journal of Engineering and Technology. 4(1): 8-14.

Nurjanah, Suseno SH, Hidayat T, Ekawati Y, Paramudhita P, Arifianto. 2015. Change Composisition chemical of skipjack tuna due to frying process. International Food Research Journal. 2(5): 2093-2102.

Nurjanah, Jacoeb AM, Hidayat T, Ulma RN, Puspitasari, Hidayat T. 2014. Komposisi kimia kupang merah (Musculista senhausia) segar dan rebus. Depik. 3(3): 241- 249

Steel RGD ,Torrie JH. 1993. Prinsip dan
Prosedur Statistika. Terjemahan: B Sumantri. Jakarta (ID) : Gramedia.

Suparmi, Desmelati, Sumarto, Sidauruk Santhy W, 2020. Fortification of various flavors in macaroni of patin fish Pangasius hypophthalmus as regional superior products. Depik. 9(1): 44-45.

Suparmi, Effendi, I, Nursyirwani, Dewita, Sidauruk SW, Windarti. 2020. The potential of hydrolyzed, concentrated, and isolated protein from Acetes erythraeus as natural antioxidant. $A A C L$ Bioflux.13(3):1292-1299.

Suparmi, Edison, Sari IN, Sumarto, Susilo R. 2020. Study of the quality of natural flavor powder made from shrimp waste. IOP Conference Series: Earth And Enviromental Science. 430. 012007. 10. 1088/1755-1315/430/1/012007.

Suryono, M, Harijono, Yunianta. 2013. Pemanfaatan ikan tuna (yellowfin tuna), ubi jalar (Ipomea batatas) dan sagu (Metroxylon sago) dalam pembuatan kamaboko. Jurnal Teknolgi Pertanian. 14(1): 9-20.

ZhangY, Gu Z, Hong, Li Z, Cheng L. 2011. Pasting and rheologic properties of potato starch and maize starch mixture. Starch. 63:11-16 